\title{
PANDANGAN ULAMA TERHADAP KONTRAK HIBRID DAN PELAKSANAANNYA DALAM PRODUK PEMBIAYAAN PERUMAHAN AFFIN HOME INVEST-I
}

\author{
Mohd Hashim Yunus*, Zamzuri Zakaria dan MD Yazid bin Ahmad \\ Jabatan Syariah Fakulti Pengajian Islam \\ Universiti Kebangsaan Malaysia, Bangi Selangor \\ *Corresponding author: mohdhashimbinyunus@yahoo.com
}

Article history

Received: 2015-08-20
Received in revised form: 2016-04-12

\begin{abstract}
Hybrid contract is a contract that combines various contract principles in a product or an activity. There are various Islamic scholars'views on permissibility of practicing the hybrid contracts. The concept of combination of various contracts are applied in Islamic funding institutions in Malaysia through the principle of Musharakah Mutanaqisah (Diminishing Partnership). The Affin Home Invest-i practices Musharakah Mutanaqisah. The objective of this research is to identify the Islamic scholars' views on hybrid contracts and study on its enforcement in housing finance based on the prinsiple of Musharakah Mutanaqisah in the Affin Home Invest-i at Affin Islamic Bank Berhad. This is a qualitative research with content analysis approach and semi-structure interviews. Results of this research indicates that arguments of the Islamic scholars who permit the combination contract is in high demand and consistent with current needs. This research also found that Affin Islamic Bank Berhad applies the housing finance based on the principle of Musharakah Mutanaqisah by combining the contract of shirkah (partnership), ijarah (renting), and purchase.
\end{abstract}

Keyword: Hybrid contracrt, Musharakah Mutanaqisah (Diminishing Partnership), Affin Home Invest-i Abstrak

Kontrak hibrid merupakan kontrak yang menggabungkan beberapa prinsip akad dalam sesuatu produk atau aktiviti. Ulama berbeza pandangan tentang keharusan penggunaannya. Konsep penggabungan akad dilaksanakan dalam produk pembiayaan perumahan secara Islam oleh institusi kewangan Islam di Malaysia. Antaranya melalui prinsip Musharakah Mutanaqisah. Produk Affin Home Invest-i merupakan produk yang mengamalkan Musharakah Mutanaqisah. Objektif kajian ini adalah untuk mengenalpasti pandangan ulama mengenai kontrak hibrid seterusnya mengkaji kontrak hibrid di dalam pelaksanaan pembiayaan perumahan Affin Home Invest-i di Affin Islamic Bank Berhad. Kajian berbentuk kualitatif dengan menggunakan pendekatan analisis kandungan dan temubual separa struktur. Hasil kajian mendapati bahawa hujah-hujah ulama yang mengharuskan penggabungan akad adalah lebih kuat dan sesuai dengan keperluan semasa. Kajian juga mendapati bahawa Affin Islamic Bank Berhad melaksanakan produk Affin Islamic Bank Berhad menggunakan prinsip MM melalui penggabungan antara akad shirkah (perkongsian), ijarah (sewa), dan jualbeli.

Kata kunci : Kontrak Hibrid, Musharakah Mutanaqisah, Affin Home Invest-i. 


\subsection{PENGENALAN}

Perkembangan industri perbankan dan kewangan Islam pada masa kini sangat mencabar dan sentiasa perlu bersaing dengan produk konvensional. Inovasi terhadap produk muamalat sentiasa berlaku dari kontrak bersifat tunggal sehinggalah terhasilnya kontrak yang multi variasi dan kontrak hibrid.

Kontrak hibrid bermaksud kontrak yang menggabungkan beberapa prinsip akad dalam sesuatu kontrak atau sesuatu produk. Kontrak gabungan ini juga disebut oleh Bank Negara Malaysia sebagai gabungan beberapa kontrak dalam satu dokumen. Secara amnya dari sudut hukum, sebahagian sarjana syariah mengharuskan kontrak hibrid manakala sebahagian yang lain menolaknya dengan hujah masingmasing.

Dalam usaha meningkatkan kepelbagaian rangkaian produk kewangan Islam yang memenuhi keperluan pelanggan, institusi kewangan Islam telah meningkatkan usaha penyelidikan dan pembangunan produk kewangan Islam. Beberapa inovasi baharu telah diterokai, antaranya dengan menghimpunkan beberapa kontrak syariah dalam satu pakej produk bagi mencapai tujuan-tujuan tertentu. Pandangan ulama yang mengharuskan kontrak hibrid diambil bagi mencapai tujuan tersebut. Produk pembiayaan perumahan secara Islam yang berasaskan Musharakah Mutanaqisah adalah contoh pelaksanaan akad hibrid yang diperkenalkan oleh beberapa perbankan Islam di Malaysia. Ia merupakan gabungan antara kontrak musharakah, bay' dan ijarah.

\subsection{LATAR BELAKANG}

Penulisan ini akan mengenal pasti perbezaan pandangan ulama tentang hukum kontrak hibrid. Penilaian terhadap hujah mereka akan dibuat dan dipilih berdasarkan pandangan yang kuat serta memenuhi kehendak semasa. Seterusnya kajian akan mengkaji produk pembiayaan perumahan Affin Home Invest-i yang dilaksanakan oleh Affin Islamic Bank Berhad yang menggunakan kontrak hibrid Musharakah Mutanaqisah. Selain menjelaskan proses pelaksanaan Musharakah Mutanaqisah dalam produk tersebut, kajian akan menganalisis sejauhmana pelaksanaan tersebut telah menepati syarat dan peraturan yang ditetapkan oleh ulama yang mengharuskan kontrak hibrid.

\subsection{PANDANGAN ULAMA MENGENAI PENGGABUNGAN AKAD}

Apabila diteliti pandangan para ulama terhadap konsep penggabungan akad, dapat dirumuskan terdapat dua pandangan yang berbeza iaitu pandangan yang mengharamkannya dan pandangan yang mengharuskannya. Keadaan ini timbul kerana dua faktor iaitu perbezaan dalam menetapkan hukum asal dalam aktiviti atau kontrak muamalah, sama ada ia bermula dengan harus atau haram. Seterusnya terdapat nas daripada hadis yang mengharamkan aktiviti yang ada kaitan dengan penggabungan akad. Hadis tersebut mengenai larangan untuk menghimpunkan akad jual beli dan akad pinjaman (bay' wa salaf), menggabungkan dua kontrak jual beli dalam satu kontrak (bay 'atayn fi bay'ah), dan menggabungkan dua transaksi dalam satu transaksi (safqatayn fi safaqah). Berdasarkan keadaan ini, timbul persoalan berkenaan status produk-produk hibrid dalam institusi kewangan Islam semasa hari ini di sisi syarak.

\subsection{PANDANGAN ULAMA YANG MENGHARAMKAN PENGGABUNGAN AKAD.}

Sebahagian ulama terutama dari kalangan Zahiriyyah mengharamkan penggabungan akad. Bagi mereka hukum asal dari akad adalah dilarang dan batal kecuali yang ditunjukkan harus oleh agama. Kalangan Zahiriyyah beralasan bahawa Islam sudah sempurna, sudah dijelaskan apa yang diperlukan oleh manusia. Setiap perbuatan yang tidak disebutkan dalam nas agama bererti membuat ketentuan sendiri yang tidak ada dasarnya dalam agama. Perbuatan seperti ini dianggap melampaui batas agama, seperti mana dinyatakan dalam al-Quran: 


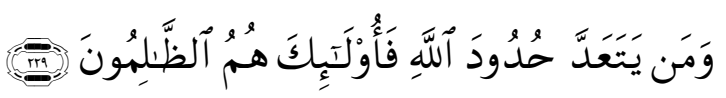

Terjemahan: Barangsiapa melampaui ketentuan-ketentuan Allah, maka merekalah orang-orang yang zalim.

(al-Baqarah, 2:229)

Akad dan syarat yang tidak diajarkan oleh agama adalah bentuk tindakan melampaui ketentuan agama dan membuat hal baru dalam agama. Hal ini kerana Allah telah menyempurnakan Islam semasa hayat Nabi Muhammad s.a.w., seperti dijelaskan dalam al-Quran:

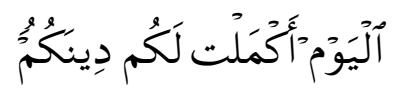

Terjemahan: Pada hari ini telah Aku sempurnakan untukmu agamamu

(al-Ma'idah, 5:39)

Berdasarkan kenyataan di atas, ulama Zahiriyyah menyimpulkan bahawa hukum asal dari akad adalah dilarang, kecuali yang dinyatakan harus oleh agama. Dalil lain yang digunakan untuk meyokong pendapat mereka ialah hadis daripada Aisyah bahawa Nabi Muhammad bersabda yang bermaksud, "Tiadalah sekelompok orang membuat syarat-syarat (perjanjian) yang tidak terdapat dalam al-Quran?. Setiap perjanjian yang tidak dinyatakan dalam al-Quran hukumnya batal, meskipun seratus perjanjian. Ketentuan Allah lebih benar dan perjanjian-Nya lebih kuat".

Menurut hadis ini, semua akad, syarat, dan janji dilarang selama tidak sesuai dengan apa yang telah dijelaskan dalam al-Qur'an dan hadis Nabi s.a.w. Ertinya, akad yang diharuskan hanyalah akad yang telah dijelaskan dalam dua sumber hukum tersebut (Ibn Hazm t.th).

Terdapat beberapa hadis yang melarang tiga bentuk gabungan akad; (bay' wa salaf), menggabungkan dua kontrak jual beli dalam satu kontrak (bay'atayn fi bay'ah), dan menggabungkan dua transaksi dalam satu transaksi (safqatayn fi safaqah). Antaranya hadis riwayat Abu Hurairah yang menyatakan yang bermaksud, "Rasulullah melarang jual beli dan pinjaman". (Musnad Ahmad 1414H: 178).

Ibn Qayyim berpendapat bahawa Nabi s.a.w. melarang gabungan antara akad salaf (memberi pinjaman atau qard) dan jual beli, meskipun kedua-dua akad itu status hukumnya adalah harus apabila bersendirian. Larangan menghimpunkan salaf dan jual beli dalam satu akad untuk menghindari terjerumus kepada riba yang diharamkan. Hal itu terjadi apabila seseorang meminjamkan (qard) seribu sebagai contoh, kemudian menjual barang yang bernilai lapan ratus dengan harga seribu. Dia seolah-olah memberi seribu dan barang seharga lapan ratus agar mendapatkan bayaran seribu. Di sini ia memperoleh lebihan dua ratus.

Selain gabungan akad antara salaf dan jual beli yang diharamkan, ulama juga sepakat melarang gabungan akad antara pelbagai jual beli dan qard dalam satu transaksi (Ibn Rushd 1379H; Ibn Qudamah $1410 \mathrm{H})$. Semua akad yang mengandungi unsur jual beli dilarang untuk dihimpunkan dengan qard dalam satu transaksi, seperti antara ijarah dan qard, salam dan qard, sarf dan qard dan sebagainya.

\subsection{PANDANGAN ULAMA YANG MENGHARUSKAN PENGGABUNGAN AKAD}

Majoriti ulama Hanafi, sebahagian pendapat ulama Maliki, ulama Shafie, dan Hanbali berpendapat bahawa hukum penggabungan akad adalah sah dan diharuskan menurut Syarak. Mereka berhujah bahawa ia selaras dengan hukum asal akad adalah harus, dan tidak ditegah selama mana tidak ada dalil yang mengharamkannya (al-Imrani 2006). Menurut Ibn Taymiyyah (1405H), hukum asal dari segala muamalat di dunia adalah harus kecuali yang diharamkan Allah dan Rasul-Nya, tiada yang haram kecuali yang diharamkan oleh Allah, dan tidak ada agama kecuali yang disyariatkan-Nya. Demikian pula dengan Ibn al-Qayyim (1374H) dan Hammad Nazih (2005) yang berpendapat bahawa hukum asal dari akad dan 
syarat adalah sah, kecuali yang dibatalkan atau diharamkan oleh Allah. Ini menurut mereka merupakan pendapat yang sahih.

Walau bagaimanapun, keharusan menggabungkan beberapa akad bukan bererti ia boleh dilakukan secara bebas, tetapi ada syarat-syarat yang mesti dikuti. Syarat-syarat berikut merupakan pengecualian kepada hukum asal keharusan penggabungan akad:

i. Gabungan akad yang jelas dilarang melalui nas. Ibn Qayyim berpendapat bahawa Nabi s.a.w. melarang gabungan akad antara akad salaf (memberi pinjaman atau qard) dan jual beli, meskipun hukum asal akad itu secara bersendirian adalah harus ( Ibn Qayyim al-Jawziyyah $1374 \mathrm{H}$ ). Meskipun penggabungan akad qard dan jual beli ini dilarang, namun ia tidak selamanya dilarang (al-'Imrani 2006). Penghimpunan dua akad ini diharuskan apabila tidak ada syarat di dalamnya dan tidak ada tujuan untuk menaikkan harga melalui qard. Seperti seseorang yang memberikan pinjaman kepada orang lain, lalu beberapa waktu kemudian ia menjual sesuatu kepada orang tersebut padahal waktu pinjaman belum lagi tamat.

ii. Gabungan akad sebagai hilah ribawi. Gabungan akad yang menjadi hilah ribawi dapat berlaku melalui kesepakatan jual beli inah atau sebaliknya dan hilah riba fadl. Contoh kes inah yang dilarang adalah menjual sesuatu dengan harga seratus secara tertangguh dengan syarat pembeli harus menjualnya kembali kepada penjual dengan harga lapan puluh secara tunai ( Ibnu Qayyim 1374 H).

iii. Gabungan akad yang menyebabkan riba. Dalam keadaan ini, akad salaf dengan jual beli digabungkan sebagaimana larangan Nabi s.a.w. daripada menggabungkan akad jual beli dan salaf. Larangan ini adalah untuk mencegah (dhari 'ah) jatuh kepada yang diharamkan berupa transaksi ribawi (al-Nawawi 1412H). Begitu juga gabungan akad antara qard dan hibah kepada pemberi pinjaman. Dalam hal ini, ulama bersepakat mengenai pengharaman qard yang diikuti dengan persyaratan imbalan lebih, berupa hibah atau lainnya. Seperti contoh, seseorang meminjamkan (memberikan hutang) suatu harta kepada orang lain. Transaksi seperti ini dilarang kerana mengandungi unsur riba. Apabila transaksi pinjaman ini kemudiannya disertai hadiah, tetapi dilakukan sendiri secara sukarela oleh orang yang diberi pinjaman tanpa disyaratkan sebelumnya, maka hukumnya adalah halal, kerana tidak mengandungi unsur riba (Ibnu Taimiyyah 1398 H).

iv. Kalangan ulama Maliki mengharamkan gabungan akad antara yang berbeza ketentuan hukumnya. Oleh itu, ulama Maliki melarang gabungan akad yang berbeza hukumnya, seperti antara jual beli dengan ju'alah, sarf, musaqah, shirkah, qirad, atau nikah. (al-'Imrani 2006).

Menurut pendapat Ibn Taimiyah, istidlal dengan dalil-dalil yang dijadikan dasar oleh kalangan Zahiriyyah ini dapat dipatahkan dengan nas-nas lain, selain kesesuaiannya dengan perkembangan manusia terutama dalam bidang muamalah dan kewangan. Nas-nas yang disebutkan oleh pendapat pertama membuktikan bahawa agama tidak membatasi manusia secara sempit dalam urusan muamalahnya. Justeru itu agama memberi peluang kepada manusia untuk melakukan inovasi dalam bidang muamalah agar memudahkan dalam kehidupan keseharian. Islam adalah agama yang memberi kemudahan bagi hambanya. Dan apa yang dijelaskan dalam nas dan hadis yang melarang di atas, bukan bererti menutup segala akad sehingga hukumnya haram.

Oleh itu, akad-akad yang tidak disebutkan dalam al-Qur'an dan hadis bukannya diharamkan, bahkan bagi umat Islam diberi kesempatan untuk melakukan inovasi. Seperti dalam hadis Nabi s.a.w. daripada Anas yang bermaksud, "Bahawa Nabi shallallahu 'alaihi wasallam pernah melewati suatu kaum yang sedang mengacukkan pohon kurma lalu baginda bersabda, "Sekiranya mereka tidak melakukannya, kurma itu akan (tetap) baik". Tapi setelah itu, ternyata kurma tersebut tumbuh dalam keadaan rosak. Hingga suatu saat Nabi shallallahu 'alaihi wasallam melewati mereka lagi dan melihat hal itu baginda bertanya, "Ada apa dengan pohon kurma kalian?" Mereka menjawab, "Bukankah anda telah mengatakan hal ini dan hal itu?". Baginda lalu bersabda, "Kalian lebih mengetahui urusan dunia kalian" (Sahih Muslim 306-361 H: 1836) 
Dengan demikian, manusia diberikan kolonggaran dalam urusan mumalah mereka. Hal ini termasuklah dalam pembentukkan akad yang boleh dilaksanakan selama mana ia tidak bercanggah dengan syarak.

Selain itu, akad juga diperlukan jika dilihat kepada keperluan dan peredaran zaman. Perkembangan mutakhir ini membuktikan bahawa banyak praktik muamalah dan transaksi kewangan yang belum pernah diamalkan pada masa Nabi dan tidak disebutkan secara jelas hukumnya. Keperluan kepada akad transaksi baharu menjadi sebuah keperluan seiring dengan pertumbuhan manusia. Kalangan ulama Malikiyah dan Hanabilah khususnya Ibn Taymiyyah berpendapat bahawa gabungan beberapa akad merupakan jalan keluar dan kemudahan yang diharuskan dan oleh syarak selagi ia mengandungi manfaat dan tidak dilarang agama. Hal ini kerana kaedah asalnya adalah sah syarat untuk semua akad selama tidak bertentangan dengan agama dan bermanfaat bagi manusia (Ibnu Taimiyyah 1368H).

Berdasarkan perkara di atas, dapat disimpulkan bahawa melalui metod muqaranah dan tarjih, pendapat yang mengharuskan adalah lebih kuat dan sesuai dengan perkembangan zaman dibandingkan dengan pendapat yang tidak mengharuskan. Ini berdasarkan kepada beberapa hujah ('Imrani 2006):

i. Dalil yang digunakan pendapat pertama memiliki status yang kuat dan mengandungi makna yang jelas.

ii. Kesesuaian dengan tujuan syariah (maqasid al-sharicah), iaitu adanya kemudahan dalam muamalah, keringanan dalam beban, dan memberi peluang inovasi.

iii. Relevan dengan perkembangan zaman dan keperluan manusia terhadap transaksi dan akad-akad moden.

Dalam hal ini, al-'Imrani (2006) mengulas seperti berikut:

"Majoriti ulama Hanafiyyah, sebahagian pendapat ulama Malikiyyah, ulama Shafiiyyah, dan Hanbali berpendapat bahawa hukum gabungan beberapa kontrak adalah sah dan diharuskan menurut hukum Syarak. Ulama yang mengharuskan berhujah bahawa hukum asal daripada akad adalah harus dan sah, tidak diharamkan dan dibatalkan selama tidak ada dalil yang mengharamkan atau membatalkannya. Kecuali menggabungkan dua akad yang menjadikannya riba atau menyerupai riba, seperti menggabungkan akad qard dengan akad yang lain, kerana adanya larangan hadis menggabungkan akad jual beli dan qard. Demikian pula menggabungkan jual beli tertangguh (ansuran) dengan jual beli tunai dalam satu transaksi”.

Penulis cenderung dengan pendangan di atas yang mengharuskan penggabungan akad kerana menepati dengan kaedah fiqh "Hukum asal dalam urusan muamalat adalah harus". Kaedah fiqh ini terbentuk daripada pelbagai unsur syarak, dan di dalam kontrak Musharakah Mutanaqisah tidak terdapat sesuatu yang menyalahi nas syarak dan juga bertentangan dengan kaedah fiqh yang umum ini. Oleh itu, menurut pandangan Muhammad 'Uthman Shabir, kontrak Musharakah Mutanaqisah adalah diharuskan menurut pandangan syarak. Penulis berasa cenderung dengan pandangan beliau kerana akad Musharakah Mutanaqisah merupakan salah satu instrumen pembiayaan dan pelaburan yang baharu, perwujudan daripada pelbagai tujuan atau motif dan faedah yang terkadang tidak tidak wujud dalam bentuk syarikat yang sedia ada. Hal ini berdasarkan kepada adanya jaminan dalam akad Musharakah Mutanaqisah ke atas tujuan pembentukan sharikat pada umumnya iaitu untuk melipat gandakan keuntungan, saling berkongsi untuk menanggung risiko dan kerugian.

Penulis bersetuju dengan pandangan yang mengharuskan akad Musharakah Mutanaqisah dengan beberapa alasan:

a. Dari sudut pendalilan

Tiada dalil khusus yang jelas mengharamkan konsep penggabungan akad. Kajian tidak menemui sebarang dalil yang mengharamkan penggabungan akad. Penggabungan akad tidak bercanggah dengan dalil-dalil umum yang mengharuskan konsep perkongsian dan kerjasama. Dalil adalah seperti berikut: 
i. Al-Quran

Firman Allah s.w.t.:

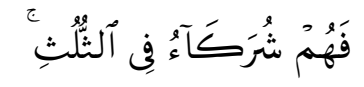

Terjemahan: Maka mereka berkongsi dalam sepertiga harta.

(al-Nisa’ 4:12)

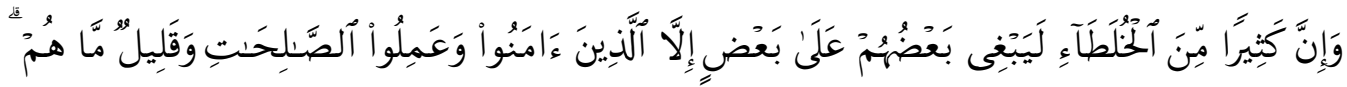

Terjemahan: Dan sesungguhnya kebanyakan daripada orang yang berkongsi itu sebahagian daripada mereka berbuat zalim pada sebahagian yang lain, kecuali orang-orang yang beriman dan mengerjakan amal-amal soleh; dan amat sedikit mereka ini.

$(\operatorname{Sad} 38: 24)$

ii. Hadith

Sabda Rasul Allah s.a.w.:

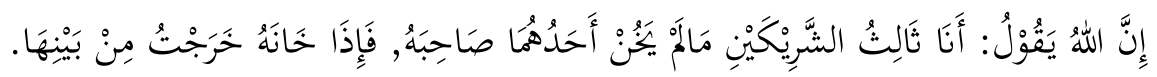

Maksudnya: Aku adalah orang ketiga bagi dua pihak yang bersyarikat selagi salah satu pihak tidak mengkhianati yang lain. Apabila berlaku pengkhianatan, Aku keluar daripada persyarikatan tersebut (Dipetik dari Abd Mumin Abd Ghani 1999: 384)

iii. Qiyas (analogi)

Adalah hal yang diperbolehkan untuk menghimpunkan akad musharakah dengan akad jual beli dalam akad Musharakah Mutanaqisah, atau akad musharakah dengan akad ijarah. Hal ini adalah sah menurut pandangan syarak dengan dianalogikan ke atas pandangan ulama yang mengharuskan untuk mengumpulkan akad pinjaman (qard) dan sharikah, bay dan ijarah, atau ijarah dan salam. Berkaitan hal itu, Ajil Jasim al-Nashimi berpandangan bahawa "sebagaimana diharuskannya untuk menghimpunkan akad sharikah dan akad jual beli dalam akad Musharakah Mutanaqisah, begitu juga diperbolehkan untuk menghimpunkan akad bay dan ijarah dalam akad Musharakah Mutanaqisah". Hal ini adalah harus menurut pandangan ulama mazhab Maliki dan Hanbali; kerana kedua-dua akad tersebut termasuk ke dalam kategori akad-akad lazim, dan mengumpulkan akad-akad lazim dalam suatu akad adalah harus sama ada ia disepakati hukumnya oleh fukaha ataupun masih terjadi ikhtilaf selagi mana ia telah memenuhi rukun dan syarat akad tersebut yang selari dengan hukum syarak.

iv. Kaedah Fiqh

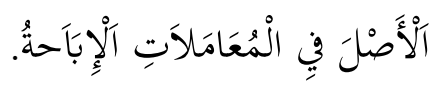

Maksudnya: Hukum asal dalam urusan muamalah adalah harus.

Kaedah fiqh ini terbentuk daripada pelbagai unsur-unsur syarak, dan di dalam kontrak Musharakah Mutanaqisah tidak terdapat sesuatu yang menyalahi nas syarak dan juga tidak bertentangan dengan kaedah fiqh yang umum ini. Oleh itu, menurut pandangan Muhammad 'Uthman Shabir, kontrak Musharakah Mutanaqisah adalah diharuskan menurut pandangan syarak (Nur al-Din 'Abd al-Karim alKiwamalah 2006:97) 


\section{b. Konsep kontrak}

Konsep Musharakah Mutanaqisah jelas tidak bercanggah dengan tujuan asas dalam sesuatu kontrak iaitu redha meredhai dan tolong menolong. Penulis merujuk kepada ayat al-Quran firman Allah dalam surah al-Māidah (3:2), yang bermaksud "Tolong menolonglah kamu dalam berbuat kebaikan dan taqwa dan janganlah kamu tolong menolong dalam berbuat dosa dan permusuhan dan takutlah kau kepada Allah, sesungguhnya Allah sangat keras seksaannya."

Penulis berpendapat bahawa pembentukkan Musharakah Mutanaqisah memberikan kemudahan kepada masyarakat dalam memiliki harta seperti rumah. Malah ia menjadi alternatif kepada produk pembiayaan perumahan yang tidak patuh syarak. Ini dapat mengelak masyarakat daripada terjebak dengan unsur riba yang diharamkan oleh syarak. Oleh itu, jelas bahawa Musharakah Mutanaqisah bukan sahaja mengandungi maslahah bahkan ia boleh menolak mafsadah.

\subsection{AMALAN PENGGABUNGAN AKAD DALAM PRODUK PEMBIAYAAN PERUMAHAN DAN OPERASI PEMBIAAYAN PERUMAHAN AFFIN HOME INVEST-I}

Affin Bank Berhad (AFBB) memulakan operasinya pada bulan Januari 2001 selepas berlakunya penggabungan antara dua buah bank iaitu Perwira Affin Bank Berhad dan BSN Commersial (M) Berhad pada bulan Ogos 2000. Pada bulan Jun 2005, ia bergabung pula dengan Affin ACF Finance Berhad. Setakat ini bank tersebut mempunyai 82 cawangan seluruh negara. Bangunan ibu pejabat yang dipanggil Menara Affin Islamic Bank Berhad (AIBB) terletak di Jalan Raja Chulan Kuala Lumpur. Affin Islamic Bank Berhad merupakan subsidiari kepada Affin Bank. Ditubuhkan pada 1 April 2006, bank yang menjalankan perbakan Islam sepenuhnya dan melancarkan produk dan khidmat untuk perbankan Pengguna dan Enterprise. Pembiayaan perumahan secara Islam di AIBB adalah produk yang berasaskan Musharakah Mutanaqisah. Terdapat juga produk pembiayaan perumahan berasaskan tawarruq adalah seperti Home Financing-i, Affin Tawarruq Home Financing-i, Business Premisses Financing-i, Afin Tawarruq BP Financing-i, Personal Financing-i, Affin Tawarruq Term Financing-i, dan Affin Tawarruq Cash Line-i. Secara komersialnya, produk pembiayaan perumahan berasaskan MM di Affin Islamic Berhad adalah seperti Affin Home Invest-i. Affin Home Assist Plus-i, Affin Creadit Plus-i, Affin Invest Plus-i, Affin BNM Priority Sector Home Financing-i, Affin Premier Corporate Home Financing-i, Affin Extra Plus-i, Affin Home Build-i, Business Premises Financing-i dan Affin Business Premises Invest-i. Pembiayaan Pelaburan Perumahan-i (Affin Home Invest-i). Produk ini menggunakan konsep Musharakah Mutanaqisah yang merupakan fokus kajian ini.

AIBB menawarkan produk pembiayaan perumahan yang berasaskan Musharakah Mutanaqisah iaitu seperti Affin Home Invest-i, Affin Home Assist Plus-i, Affin Creadit Plus-i, Affin Invest Plus-i, Affin BNM Priority Sector Home Financing-i, Affin Premier Corporate Home Financing-i, Affin Extra Plus-i, Affin Home Build-i. Pembiayaan Pelaburan Perumahan-i (Affin Home Invest-i), satu produk baharu yang berasaskan konsep Musharakah Mutanaqisah. Produk tersebut ditawarkan kepada pelanggan untuk membiayai rumah yang belum siap dibina (under construction) dan rumah yang telah siap dibina ( completed construction). Pembiayaan Pelaburan Perumahan-i (Affin Home Invest-i) ini mula diperkenalkan pada bulan Mei 2011.

Terdapat persamaan antara rumah yang belum siap dengan yang telah siap dari segi modus operandi dan prosedur. Namun, terdapat perbezaan antara rumah yang belum siap dengan rumah yang telah siap dari segi status bayaran.

Transaksi pembiayaan perumahan di Affin Islamic Bank Berhad adalah melalui kontrak Musharakah Mutanaqisiah yang melibatkan tiga pihak iaitu:

i. Affin Islamic Bank Berhad sebagai pembiaya dan rakan kongsi

ii. Rakan kongsi yang terdiri dari pelanggan

iii. Pembekal barang atau Syarikat Pemaju Harta (Pemaju Perumahan) 
Walaupun transaksi ini melibatkan tiga pihak, kaedah pelaksanaannya masih lagi berasaskan kaedah tradisi pembelian rumah di Malaysia. Ini bermakna tidak wujud hubungan tiga pihak secara langsung sebaliknya secara tidak langsung. Yang jelasnya pelanggan akan bertransaksi dengan pemaju (Amirol Abdullah 2011).

Operasi dan prosedur pembiayaan perumahan di Affin Islamic melalui produk Pembiayaan Perumahan Ekuiti-i adalah melibatkan elemen musharakah, ijarah dan wa'd mulzim dari pihak pelanggan untuk membeli bahagian ekuiti pelanggan ke atas rumah tersebut. Gambaran operasi pembiayaan adalah seperti berikut.

\section{Rajah 4.1 Lakaran Operasi Pembiayaan Perumahan Secara Musharakah Mutanaqisah di Affin} Islamic Bank

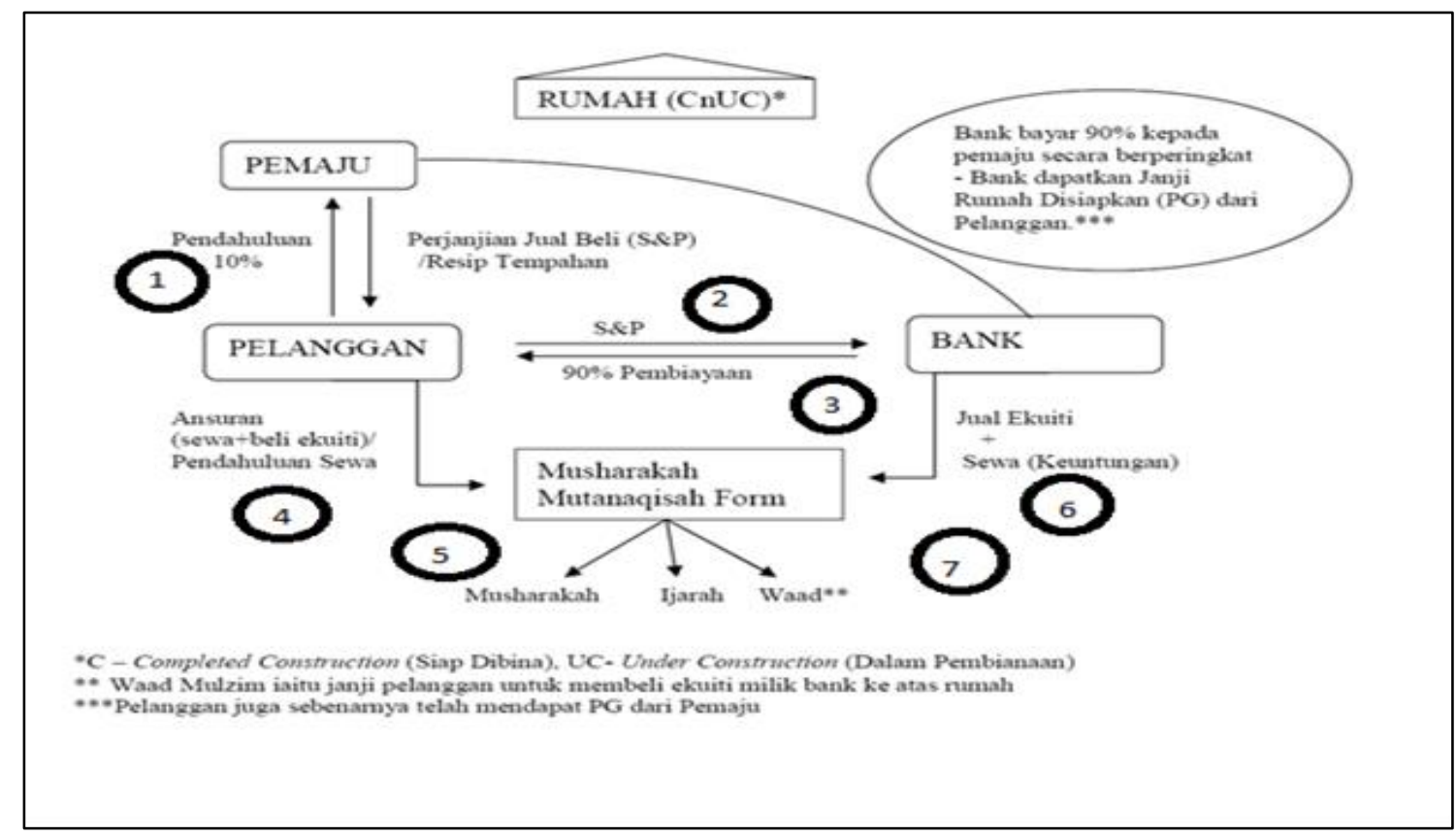

Sumber: Universiti Utara Malaysia 2012

Sebelum menemui bank, pelanggan akan mengenalpasti terlebih dulu rumah yang akan dibeli. Pelanggan kemudian membuat tempahan dengan pihak pemaju (seperti mengisi borang disediakan pihak pemaju). Proses yang berlaku adalah seperti berikut:

1. Pelanggan menemui Affin Islamic Bank untuk mendapatkan pembiayaan perumahan secara Musharakah Mutanaqisah.

2. Pihak bank akan membiayai pelanggan secara Musharakah Mutanaqisah. Sebagai rakan kongsi, pelanggan akan membayar $10 \%$ adalah deposit minimum dari pelanggan, manakala Affin Islamic Bank akan membayar baki $90 \%$ adalah pembiayaan maksimum bagi harga rumah kepada pemaju.

3. Selepas itu pelanggan akan menduduki rumah tersebut dengan membayar sewa kepada bank (bagi rumah yang telah siap). Pelanggan hanya perlu membayar sewa bergantung kepada nilai 90\% bahagian bank sahaja dalam bayaran ansurannya.

4. Pelanggan dalam masa sama akan membeli ekuiti bank secara beransur-ansur dalam pegangan hak milik rumah tersebut. Kedua-dua bayaran ini terkumpul dalam satu bayaran ansuran. Ini disebabkan pelanggan telah menandatangani perjanjian wacd untuk membeli ekuiti Affin Islamic Bank. 
5. Milikan (ekuiti) bank dalam rumah tersebut akan berkurangan atau menurun sedikit demi sedikit setelah pelanggan membelinya secara beransur-ansur sehingga tempoh pembiayaan tamat (contohnya 35 tahun).

6. Setelah tamat tempoh 35 tahun dan pelanggan membuat bayaran ansuran terakhir, pelanggan akan menerima notis akhir (fulfillment notice) dari Affin Islamic Bank yang akan menyatakan bahawa pelanggan telah memiliki sepenuhnya rumah tersebut secara individu.

\subsection{OPERASI PENGGABUNGAN AKAD DALAM AFFIN HOME-I}

Berdasarkan kepada rajah 4.1 prinsip Musharakah Mutanaqisah bermula pada langkah no. 3 yang mana penggabungan akad antaranya musyarakah, ijarah dan jualbeli berlaku. Pertama, kontrak musharakah berlaku apabila Affin Islamic bank Berhad membayar baki sebanyak 90\% harga rumah yang dibeli oleh pelanggan. Pelanggan pada awalnya telah pun membayar sebanyak $10 \%$ kepada pemaju. Oleh itu, hubungan antara pelanggan dengan Affin Islamic Bank Berhad ketika ini adalah berlakunya perkongsian pemilik sebuah rumah yang mana Affin Islamic Bank Berhad memiliki 90\% manakala pelanggan memiliki $10 \%$. Jadi, kontrak perkongsian telah berlaku disini. Bagi kontrak ijarah pula, ia berlaku apabila pelanggan menduduki rumah tersebut dan membayar sewa kepada bank khususnya bagi rumah yang telah siap. Pelanggan hanya perlu membayar sewa bergantung kepada nilai $90 \%$ pelanggan bank sahaja dalam bayaran ansurannya. Berdasarkan kepada tempoh dan syarat-syarat yang telah dipersetujui. Disini berlakunya kontrak sewa antara pelanggan dengan bank iaitu pelanggan menyewa bahagian pemilikan bank. Manakala kontrak jualbeli, ia berlaku dimana pelanggan ketika membayar sebahagian sewa, sebahagian itu adalah sewa dan sebahagian lagi adalah belian pelanggan secara beransur-ansur dalam pegangan hak milik rumah tersebut. Pembayaran sewa dan juga semua pembayaran belian berlaku ketika bayaran bulanan. Milikan (ekuiti) bank dalam rumah tersebut akan berkurangan atau menurun sedikit demi sedikit setelah pelanggan membelinya secara beransur-ansur sehingga tempoh pembiayaan tamat (contohnya 35 tahun). Setelah tamat tempoh 35 tahun dan pelanggan membuat bayaran ansuran terakhir, pelanggan akan menerima notis akhir (fulfillment notice) dari Affin Islamic Bank yang akan menyatakan bahawa pelanggan telah memiliki sepenuhnya rumah tersebut secara individu. (Amirol Abdullah, 2011).

\subsection{PANDANGAN ULAMA MENGENAI MUSHARAKAH MUTANAQISAH}

Secara umumnya, terdapat dua pandangan ulama berkaitan dengan aplikasi kontrak Musharakah Mutanaqisah, iaitu pertamanya ialah yang mengharuskan kontrak Musharakah Mutanaqisah. Kedua, pandangan ulama yang menolak atau mengharamkannya. Ulama dan pakar ekonomi Islam semasa mengharuskan kontrak Musharakah Mutanaqisah berdasarkan pandangan Syarak, selagi mana hal itu telah memenuhi Standard (dawabit) dan perundangan syariah yang harus diguna pakai dalam aplikasinya. Hal ini bertujuan agar pelaksanaan kontrak Musharakah Mutanaqisah tersebut terbebas daripada unsur keraguan (shubhah) dari pelbagai keraguan yang terkadang boleh menyebabkannya menyimpang daripada skop syariah. Antara ulama dan pakar ekonomi Islam semasa yang mengharuskan kontrak Musharakah Mutanaqisah ialah Jasim 'Ali Salim al-Shamisi, 'Ajil Jasim al-Nashimi, Ahmad Muhyi alDin Ahmad, 'Abd al-Sattar Abu Ghuddah, Hasan 'Ali al-Shadhili, Wahbah al-Zuhayli, Nazih Kamal Hammad, 'Abd al-Salam al-'Ibbadi, Qutb Mustafa Sanu, dan Muhammad 'Uthman Shabir (Nur al-Din alKiwamilah 2005). Para ulama berpandangan bahawa mereka tidak menemui satu dalil khusus yang menjelaskan iaitu dengan mengharamkan konsep penggabungan akad. Ulama yang menolak atau mengharamkan kontrak Musharakah Mutanaqisah bersandarkan kepada dalil 'aqli yang diasaskan ke atas pemahaman mereka terhadap sharikah dan dawabitnya dalam perundangan Islam. Adapun inti atau kesimpulan daripada pandangan mereka telah menyatakan bahawa pada intipatinya dalam kontrak Musharakah Mutanaqisah itu terdapat banyak unsur keraguan. Melalui kajian ke atas pelaksanaan produk Affin Home Invset-i di dapati ia telah mengambil pandangan mengharuskan. Pelaksanaannya juga telah mengikuti syarat-syarat di tetapkan dengan tidak menggabungkan akad yang ditegah.

\subsection{KESIMPULAN}

Konsep akad hibrid merupakan penggabungan beberapa akad di dalam satu kontrak seperti menggabungkan akad syarikah, ijarah dan jualbeli. Mengenai hukum kontrak hibrid ini terdapat dua 
Mohd Hashim Yunus et.al. / UMRAN - International Journal of Islamic and Civilizational Studies. vol. 3, no. 3 (2016) 39-48

pandangan ulama pertama, ulama yang mengharamkannya dan kedua ulama yang mengharuskannya. Daripada hujah-hujah pandangan yang mengharuskan itu adalah lebih menepati dengan keperluan manusia hari ini. Walaubagaimana pun, ulama yang mengharuskan telah menetapkan beberapa syarat yang perlu diikuti bagi menjadikannya harus untuk diamalkan. Amalan penggabungan akad sememangnya berlaku dalam produk kewangan hari ini. Antaranya produk pembiayaan perumahan Affin Home Invest-i yang ditawarkan oleh Affin Islamic Bank Berhad. Produk ini telah menggunakan prinsip Musharakah Mutanaqisah yang menggabungkan kontrak syarikah, ijarah dan jualbeli. Hasil kajian mendapati bahawa pelaksanaan kontrak hibrid di dalam produk Affi Home Invest -i ini adalah memenuhi pandangan dan syarat yang ditetapkan keatas pelaksanaan kontrak hibrid di dalam muamalah Islam. Produk sebegini adalah cukup penting di dalam memenuhi keperluan dan kehendak manusia dan institusi kewangan zaman kini.

\section{Rujukan}

al-Quran al-Karim

Abd Mumin Abd Ghani. (1999). Sistem Kewangan Islam dan Pelaksanaan di Malaysia. Kuala Lumpur: Jabatan Kemajuan Islam Malaysia.

Abu 'Abd Allah Ahmad Ibn Hanbal. (1414 H). Musnad Ahmad, juz 2. Beirut: Dar al-Ihya al-Turash al-'Arabi.

al-'Imrani, 'Abd Allah ibn Muhammad ibn 'Abd Allah. (2006). al-'Uqud al-Maliyyah al-Murakkabah: Dirasah Fiqhiyyah Ta'siliyah wa Tatbiqiyyah. Riyad: Dar Kunuz Ishbilia li al-Nashr wa al-Tawzi’.

al-Nawawi, Abu Zakariyya Yahya ibn Sharaf. (1412H). Rawdat al-Talibin. juz.3. Bayrut: Dar al-Kutub.

Amirol Abdullah, Pengurus Bahagian Produk di Affin Islamic bank Berhad, Kuala Lumpur. Temubual pada 3.00 pm, 11 Februari 2011.

Hammad, Nazih. (2005). al- 'Uqud al-Murakkabah fi al-Fiqh al-Islami, Dirasah Ta'siliyyah li al-Manzumat al'Aqdiyyah al-Mustahdathah. Dimashq: Dar al-Qalam.

Ibn Hazm, Abu Muhammad 'Ali ibn Ahmad ibn Sacid. (t.th.). al-Muhalla. juz. 5. Al-Qahirah: Dar al-Turath.

Ibn Qayyim al-Jawziyyah. (1374H). I 'lam al-Muqqi 'in can Rabb al- 'Alamin. Juz.1. Misr: al-Sa'adah.

Ibn Qayyim al-Jawziyyah. (t.th.). I'lam al-Muwaqqi'in can Rab al- 'Alamin. juz. 3. Al-Qahirah: Maktabah Ibn Taymiyyah.

Ibn Qudamah. (1410H). al-Mughni. Juz 6. Riyad: Dar al-Alam al-Kutub.

Ibn Rushd. (1379H). Bidayat al-Mujtahid wa Nihayah al-Muqtasid. Juz 2, Mesir: Mustafa al-Babi al-Halabi.

Ibn Taymiyah. (1398H). Majmu 'Fatawa Ibn Taymiyyah. jil. 29. al-Riyad: al-Su’udiyyah.

Ibn Taymiyyah. (1405H). Jami` al-Rasa'il. Juz.2. Jiddah: Dar al-Madani.

Mohd Sollehudin Shuib. (2012). Kontrak Hibrid Musharakah Mutanaqisah Dalam Muamalat Islam: Analisis Isu Fiqh Dan Aplikasi Semasa di Affin Islamic Bank. Laporan Penyelidikan, Universiti Utara Malaysia.

Nur al-Din 'Abd al-Karim al-Kiwamalah. (2006). al-Musharakah al-Mutanaqisah wa Tatbiqatuha al-Mucasirah $f i$ al-Fiqh al-Islami. cet. ke-1. 'Amman: Dar al-Nafa'is. 